\title{
PRESIDENT'S REPORT FOR VOLUME 56
}

\section{Dear CBS member,}

I am honored to provide my first President's Report for the Society. Dean Kelch has transitioned to the Past President's position. CBS Recording Secretary Nishanta Rajakaruna has accepted a new position in Maine. When he leaves, Mike Vasey, a former President, will step in to take his place as Recording Secretary. Although he will be residing in Maine most of the year Dr. Rajakaruna will continue his research on Lasthenia and other California plants. Andrew Doran (1st Vice President), Rod Myatt (2nd Vice President), Heather Driscoll (Corresponding Secretary), Kim Kersh (Membership Chair) and Tom Schweich (Treasurer) continue as officers of the Society. Other members of the Council included Staci Markos, Ellen Simms, Chelsea Specht and the Graduate Student Representative Ben Carter. Thank you Susan Bainbridge for your work as Webmaster this past year. The Editors of Madroño, Rich Whitkus and Tim Lowrey, make up the remainder of the Board.

This is the first volume of Madroño edited by Drs. Whitkus and Lowrey, and they are quickly bringing the journal back under control and on time after a transitional year. They have brought a commitment to quality and professionalism that gives all of us confidence in the future of the journal.

The past year was an active time for the Board of the California Botanical Society. The Board this year is moving to bringing the Society totally online through the website. We hope to provide members with electronic access to the journal in upcoming months. Submissions of manuscripts and reviews have already converted to online submission to some extent, but may move entirely to electronic processing in the near future, along with membership renewals and other functions. We're excited by this process but are moving carefully to ensure sustainability of these improvements. Meanwhile, we also are working on getting all past issues of Madroño available through an electronic journal access website. So many classic articles are hiding in the older issues, from floras and species treatments, to insightful papers on ecology and evolution; electronic access to these articles would raise the status of the journal as well as providing us all great insight into our history as botanists of western North America.

As I write this, the Annual Banquet and Graduate Student Meeting at San Jose State University have already occurred. These were both quite successful with a fantastic talk by Doug Schemske from Michigan State University on studies of adaptation and speciation. We congratulate Susie Woolhouse (SJSU graduate student) and Rod Myatt for their exceptional work organizing this successful meeting. In fact, the graduate student talks and posters were so excellent at this meeting the judges could not agree which were the best talks for awards, so we ended up with multiple awards. Winners were Brian Anacker (UC Davis), Naomi Fraga (Rancho Santa Ana), Jennifer Goropse (San Jose State), Dena Grossenbacher (UC Davis), Matt Guilliams (UC Berkeley), Kristen Hasenstab-Lehman (Rancho Santa Ana), Stephanie Porter (UC Davis) and Jenn Yost (UC Santa Cruz). Congratulations to you all.

Our membership base is the foundation of the Society and your support allows us to promote botanical research and education. Increasing our membership is thus a priority, so please continue to encourage your colleagues to join us and to publish in Madroño. Please consider providing a sponsoring membership or subscription to a foreign scientist or scientific institution to support botanical research in economically depressed, developing countries. For more information on making such a gift, please contact Corresponding Secretary Heather Driscoll (hdriscoll@berkeley.edu). The Society also welcomes gifts or other contributions to our endowment.

Finally, I note that the Society reaches its centennial year in 2015, which is not that far away. The Board has already begun considering ideas about how to celebrate that event. We're open to ideas from the membership, so as you come up with them, please pass them along to board members.

V. Thomas Parker December 2009 


\section{$2 \mathrm{BHL}$ Biodiversity Heritage Library}

Parker, V Thomas. 2009. "President's Report for Volume 56." Madroño; a West American journal of botany 56, 296-296.

https://doi.org/10.3120/0024-9637-56.4.296.

View This Item Online: https://www.biodiversitylibrary.org/item/185050

DOI: https://doi.org/10.3120/0024-9637-56.4.296

Permalink: https://www.biodiversitylibrary.org/partpdf/168950

\section{Holding Institution}

Smithsonian Libraries

\section{Sponsored by}

Biodiversity Heritage Library

\section{Copyright \& Reuse}

Copyright Status: In Copyright. Digitized with the permission of the rights holder License: http://creativecommons.org/licenses/by-nc/3.0/ Rights: https://www.biodiversitylibrary.org/permissions/

This document was created from content at the Biodiversity Heritage Library, the world's largest open access digital library for biodiversity literature and archives. Visit BHL at https://www.biodiversitylibrary.org. 